\title{
КЛІНІКО-ПСИХОЛОГІЧНІ ФЕНОМЕНИ У ПАЦІЕНТІВ ОНКОЛОГІЧНОЇ ПРАКТИКИ НА РІЗНИХ ЕТАПАХ ЛІКУВАЛЬНОГО ПРОЦЕСУ
}

\author{
@I. P. Мухаровська
}

\section{Київський міський клінічний онкологічний центр}

РЕЗЮМЕ. У роботі проводилося вивчення провідних клініко-психологічних симптомів на етапах лікувального процесу. Дослідження проводилося на базі Київського міського клінічного онкологічного центру. Було обстежено 187 осіб, які проходили протипухлинне лікування вперше, 155 онкохворих звернулися за лікуванням повторно та 112 пацієнтів - на етапі паліативної допомоги. Провідними клініко-психологічними особливостями етапу первинного лікування були феномени «поділу життя» та «нового початку», симптоматичної допомоги «маятника», «децентралізації» та «екстерналізації», прогресування хвороби та повторна протипухлинна терапія характеризувалися зниженням значимості первинних та збільшенням паліативних феноменів. Наскрізними були феномени «індукції» та «сортера». Психологічний стан онкологічних пацієнтів формувався у взаємозв'язку з особливостями етапів лікувального процесу.

КЛЮчОВІ СЛОВА: онкологічні хворі, психологічний стан, клініко-психологічні феномени, психоонкологія, психологічна допомога.

Вступ. На сьогодні онкологічні хвороби є значною медико-соціальною проблемою. Не зважаючи на нові підходи та методи у діагностиці і лікуванні онкологічної патології відбувається неухильне зростання захворюваності. В Україні у 2014 році було зареєстровано 384,9 нових випадків на 100 тис. населення [1]. Онкопатологія спричиняє часткову чи повну втрату працездатності внаслідок хронічного прогредієнтного перебігу у кожного 6 пацієнта, летальність становить 51,3 \%, не проживає і 1 року після встановлення діагнозу 31,4 \%, смертність складає 188,4 на 100 тис. населення [1]. Ці показники вказують та високий рівень загрози для життя, що і лежить в основі переважної більшості онкопсихогеній.

Встановлення онкологічного діагнозу спричиняє суттєві зрушення у психічному стані хворого, що проявляються у різних формах психологічної дезадаптації, які можуть досягати рівня вираженості клінічно окреслених психічних розладів [2 -4]. Онкологічне захворювання змінює життєві цілі пацієнтів, лікування та боротьба з хворобою стають провідними життєвими завданнями [5]. Психосоціальними наслідками онкопатології $\epsilon$ виключення з активного професійного та соціального життя, стигматизація пацієнтів [6]. Поряд з хворими психічного травмування зазнає і його близьке оточення, медичний персонал, який надає допомогу та здійснює догляд $[7,8]$.

Розуміння закономірностей реагування хворого та особистісного змісту психологічних проявів онкологічного захворювання $\epsilon$ ключем до розробки ефективних програм медико-психологічної допомоги в онкології.

Мета дослідження полягала у виявленні провідних клініко-психологічних феноменів у онкологічних хворих на різних етапах лікування.

Матеріал і методи дослідження. Дослідження проводилося на базі Київського міського клініч- ного онкологічного центру протягом 2012 - 2016 років. Було обстежено 187 осіб (Гп), які проходили протипухлинне лікування вперше, 155 онкохворих (Гв) - звернулися за лікуванням повторно в наслідок прогресування чи рецидиву захворювання та 112 пацієнтів на етапі паліативної допомоги (Гпал). Здійснювалося спостереження за психологічним станом хворих та його динамікою у процесі протипухлинної та паліативної терапії з наступним якісним аналізом отриманих даних. Статистична обробка проводилася з використанням методів описової статистки у MS Excel v.8.0.3.

Результати й обговорення. Пацієнти, які були госпіталізовані у онкологічний заклад вперше, переживали виражений психічний стрес у зв'язку із загрозою життю, що відображалося у негативних емоціях, ситуативній дезорганізації поведінки. Вони відчували нестачу інформації щодо онкологічного захворювання, не орієнтувалися в методах лікування, а також, не володіли досвідом протидії соматичному стресу чи способами перебудовувати стиль життя відповідно до потреб і обмежень, пов'язаних з хворобою, реагували та діяли під впливом соціальних міфів щодо онкологічних хвороб. Пацієнти, госпіталізовані повторно внаслідок прогресування чи рецидиву онкологічного захворювання, отримували повторну психологічну травму. У цій групі онкохворих спостерігалося наростання фізичного нездоров'я та зниження працездатності. Однак позитивним було те, що пацієнти вже більш поінформовані щодо свого захворювання та методів лікування, мали досвід психологічної протидії впливу хворобі, формували практично-орієнтовані індивідуалізовані рішення проблем, які виникали у зв'язку із соматичною патологією. Варто зазначити, що отриманий вперше досвід міг бути 
Огляди літератури, оригінальні дослідження, погляд на проблему

як допоміжним у випадку формування адаптивних навиків, так і дезадаптуючим - при наявності виражених непережитих психотравматичних станів. Термінальний стан онкологічного захворювання характеризувався високим рівнем напруження, мінливістю, прогресивним погіршенням, невідворотністю наслідків та непідконтрольністю ситуації, виснаженням фізичного та психічного ресурсу, вітальним характером переживань.

Для онкологічних хворих був властивий ряд клініко-психологічних феноменів, які відображали особливості переживання перебігу хвороби та лікування: «поділу життя», «сортера», «нового початку», «маятника», «екстерналізації психічної напруги», «психологічної індукції», «децентралізації» (табл. 1).

Таблиця 1. Клініко-психологічні феномени на етапах лікувального процесу, \%

\begin{tabular}{|l|c|c|c|}
\hline \multicolumn{1}{|c|}{ Феномени } & Гп, $\mathrm{n}=187$ & Гв, $\mathrm{n}=155$ & Гпал, $\mathrm{n}=112$ \\
\hline «Поділу життя» & 100 & - & - \\
\hline «Сортера» & $46,5 \pm 5,0$ & $45,2 \pm 5,0$ & $57,1 \pm 4,9$ \\
\hline «Нового початку» & $91,4 \pm 2,8$ & $65,8 \pm 4,7$ & - \\
\hline «Маятника» & $27,8 \pm 4,5$ & $35,5 \pm 4,8$ & $73,2 \pm 4,4$ \\
\hline «Екстерналізації» & $15,5 \pm 3,6$ & $17,4 \pm 3,8$ & $53,6 \pm 5,0$ \\
\hline «ндукції» & $12,8 \pm 3,3$ & $16,1 \pm 3,7$ & $23,2 \pm 4,2$ \\
\hline «Децентралізації» & $9,1 \pm 2,9$ & $13,5 \pm 3,4$ & $50,9 \pm 5,0$ \\
\hline
\end{tabular}

Клініко-психологічний феномен «поділу життя» відображав різку зміну психологічного стану людини, що розділяла її життя на до та після встановлення онкологічного діагнозу. Соціальні уявлення щодо онкологічних захворювань, зокрема їх невиліковності та страждань, що приносить хвороба, відсутність стовідсоткової гарантії вилікування сучасними медичними методами навіть на ранніх стадіях викликали у хворих відчуття реальної загрози життю. Можливість смерті ставила перед пацієнтами важливі екзистенційні питання, що стосувалися сенсу їх життя, планів на майбутнє, уявлень про себе як про особистість, та власних досягнень, переоцінки цінностей. Протипухлинна терапія виключала хворих зі звичного життєвого ритму та соціальної активності. Та навіть після курсів лікування пацієнти не могли психологічно розслабитися, у них постійно був високий рівень настороженості, внаслідок того, що онкологічним захворюванням притаманні прогресуючий хронічний перебіг та рецидиви. Онкологія ставала діагнозом на все життя та нагадувала про себе потребою у періодичних оглядах, повторних курсах протипухлинної терапії. Переживання «поділу життя на до та після хвороби» були властиві кожному пацієнту при первинному зіткненні з онкологічним захворюванням - 100 \% у Гп та 0\% у Гв та Гпал.
Клініко-психологічний феномен «сортера» базувався на селективності сприйняття інформації, пов'язаної з онкологічною хворобою. Потік психотравматичних стимулів: загрозливе для життя захворювання, складне та тривале лікування, наслідки та ускладнення патології, - міг призводити до відкидання фактів реальності, вибору більш психологічно привабливих варіантів інтерпретації дійсності з метою контролю негативної інформації, самозаспокоєння, пошуку внутрішніх ресурсів подолання ситуації. Вибірковість сприйняття мала захисну функцію з однієї сторони, та вказувала на схильність до прояву незрілих форм поведінки з іншої. Вибірковість сприйняття, що лежала в основі феномену, широко простежувалася та була наскрізною, що обумовлювалося високою стресовістю ситуації - $(46,5 \pm 5,0) \%$ у Гп, $(45,2 \pm 5,0) \%$ у Гв та $(57,1 \pm 4,9) \%$ у Гпал.

Клініко-психологічний феномен «нового початку» полягав у різкому зростанні позитивних очікувань щодо лікування, надії на подолання чи тривале стримування хвороби. На фоні зіткнення з екзистенційними питаннями пацієнти приймали внутрішнє рішення кардинально змінити власне життя, зробити його більш наповненим сенсом, втілити нереалізовані бажання, налагодити стосунки з близькими чи розірвати неприємні відносини. Даний феномен характеризував стан пристосування до ситуації, формування ефективних способів його подолання. Феномен «нового початку» був властивий хворим після перших курсів протипухлинної терапії, тоді як при прогресуванні захворювання його частота зменшувалася - $(91,4 \pm 2,8) \%$ у Гп та $(65,8 \pm 4,7) \%$ у Гв, 0 \% у Гпал.

Зміна у фізичному та психічному станах хворого викликала емоційний відгук, погіршення стану супроводжувалося негативними емоціями, покращення - позитивними. Враховуючи прогресуючий перебіг онкологічної патології періодично виникали ситуації погіршення стану та покращення на фоні протипухлинного чи паліативного лікування, що формувало «ефект маятника» - коливання психоемоційного стану від «полюсу надії» до «полюсу розпачу». Відсутність інших механізмів адаптації поза суто емоційним відреагуванням спричиняло швидке виснаження, що було однією з ознак дезадаптації. Даний феномен був типовим для хворих у термінальному періоді, коли мали значення найменші зміни у фізичному стані - $(27,8 \pm 4,5) \%$ у Гп, $(35,5 \pm 4,8) \%$ у Гв та $(73,2 \pm 4,4) \%$ у Гпал.

Клініко-психологічний феномен «екстерналізації психічної напруги». Онкохворі під час хвороби та іï лікування переживали інтенсивний фізичний та психічний стрес. Одним зі способів зменшення внутрішнього напруження було винесення причи- 
Огляди літератури, оригінальні дослідження, погляд на проблему

ни його виникнення поза межі власного «я», передача відповідальності комусь або чомусь сторонньому, наприклад, списування погіршення стану на побічну дію препаратів, «невірно» вибрану тактику лікування, неправильно призначені лікарські засоби, халатність медперсоналу. Об'єктом зміщення могло стати будь-що, однак найчастіше ним були нещодавно призначені ліки та проведені процедури, і відповідно медичний персонал відповідальний за їх призначення чи виконання.

Суть «індукції» полягала у формуванні співзалежності психоемоційного стану у діаді «хворий родич». Індуктором міг виступати як пацієнт, так i член сім'ї. Важливими умовами реалізації індукції були конформність, залежні стосунки та високий рівень переживання почуття провини у одного з учасників діади. Дезадаптивний характер індукування був обумовлений розмитістю персональної відповідальності за ситуацію, непрозорістю та складністю міжперсональних стосунків, зазвичай частими конфліктами з медичним персоналом. Феномени «екстерналізації» - $(15,5 \pm 3,6) \%$ у Гп, $(17,4 \pm 3,8) \%$ у Гв та $(53,6 \pm 5,0) \%$ у Гпал, та «психологічної індукції» $(12,8 \pm 3,3) \%,(16,1 \pm 3,7) \%$ та $(23,2 \pm 4,2) \%$, були притаманні хворим з особистісною предиспозицією, що включала риси психологічної незрілості, демонстративності, слабкої вольової регуляції, емоційної нестійкості, а також спостерігалися на фоні вираженої фізичної чи психічної астенії.

Клініко-психологічний феномен «децентралізації» включав концентрування уваги на вторинних, менш значимих ознаках. Прикладами застосування даного механізму у онкологічних хворих були ситуації, коли на основі послаблення лише одного 3 симптомів, несуттєвих змін лабораторних показників, незважаючи на картину в цілому, робився висновок щодо суттєвого покращення стану, або ж поява нових чи посилення раніше присутніх симптомів захворювання приписувалися не пов'язаним 3 хворобою чинникам (погода, застуда, порушення дієти, фізичне перевантаження, побічна дія препаратів чи їх передозування, інші хвороби). Таким чи- ном, ознаки прогресування хвороби нівелювалися та розривався причинний зв'язок з захворюванням. Чим більше психоемоційне напруження переживав хворий, тим більшою була потреба у викривленні реальності. Позитивні зрушення у соматичному та психічному станах пацієнта викликали більший психологічний відгук, що проявлялося перебільшенням їх значення, тоді як негативна (психотравмуюча інформація) трансформувалася у більш прийнятну форму (знецінення значимості симптому) або ігнорувалася. Феномен "децентралізації» найчастіше спостерігався у паліативній допомозі, що було обумовлено суттєво більшим значенням симптому для інтерпретації прогнозу, порівняно з періодами первинного та повторного лікування - $(9,1 \pm 2,9) \%$ у Гп, $(13,5 \pm 3,4) \%$ у Гв та $(50,9 \pm 5,0) \%$ у Гпал.

Отримані дані вказували, що формування психологічного стану онкологічних пацієнтів відбувалося у взаємозв'язку з особливостями кожного з етапів лікувального процесу.

Висновки. 1. У онкологічних хворих були присутні клініко-психологічні феномени, які відображали особливості переживання перебігу хвороби та лікування: «поділу життя», «сортера», «нового початку», «маятника», «екстерналізації психічної напруги», «психологічної індукції», «децентралізації».

2. Провідними клініко-психологічними особливостями етапу первинного лікування були феномени «поділу життя» та «нового початку», симптоматичної допомоги - «маятника», «децентралізації» та «екстерналізації», прогресування хвороби та повторна протипухлинна терапія характеризувалися зниженням значимості первинних та збільшенням паліативних феноменів. Наскрізними були феномени «індукції» та «сортера».

3. Психологічний стан онкологічних пацієнтів формувався у взаємозв'язку з особливостями кожного з етапів лікувального процесу.

Перспективи подальших досліджень у даній сфері лежать у виявленні закономірностей та клініко-психологічних феноменів відреагування родини онкологічного хворого.

\section{ЛІТЕРАТУРА}

1. Федоренко 3. П. Рак в Україні 2013-2014 [Текст] / [3. П. Федоренко, Л. О. Гулак, Ю. Й. Михайлович та ін.]; ред. О. О. Колеснік. - К.: Національний інститут раку, 2015. - Режим доступу: http://www.ncru.inf.ua/ publications/BULL_16/index.htm

2. Савин А. И. Особенности психогенно обусловленных психических расстройств и психологические характеристики онкологических больных при разных опухолевых локализациях (подход к проблеме) / А. И. Савин, Б. Ю. Володин // Наука молодых EruditioJuvenium. - 2015. - № 3. - C. 82 - 86.
3. Некоторые психологические характеристики онкобольных в связи с особенносями психокоррекционной работы / Н. З. Кайгородова, О. М. Любимова, В. Д. Петрова, О. В. Парамонова // Известия Алтайского государственного университета. - 2014. - Т. 2, № 2 (82). - С. 22-26.

4. Кучин Ю. Л. Проблемы делирия у онкологических пациентов [Электронный ресурс] / Ю. Л. Кучин // Здоровье Украины. - 2015. - № 1. - Режим доступу: http://health-ua.com/stati/onkologiya-i-gematologiya. html 
Огляди літератури, оригінальні дослідження, погляд на проблему

5. Life and treatment goals of patients with advanced, cancer / R. D. Nipp, A. El-Jawahri, J. N. Fishbein [et al.] // incurable cancer / K. L. Rand, D. A. Banno, A. M. Shea, L. D. Cripe //Support Care Cancer. - Vol. 24 (7). -P.2953-2962.

6. Psycho-Oncology / J. C. Holland, W. S. Breitbart, P. B. Jacobsen [et al.]. - Oxford University press, 2015. - 772 p.

7. Factors associated with depression and anxiety symptoms in family caregivers of patients with incurable Annual of Oncology. - 2016. - Vol. 27(8). - P. 16071612.

8. Russell K. Perceptions of Burnout, Its Prevention, and Its Effect on Patient Care as Described by Oncology Nurses in the Hospital Setting / K. Russell // Oncol. Nurs. Forum. - 2016. - Vol. 1, Issue 43(1). - P. 103-109.

\section{THE PSYCHOLOGICAL PHENOMENON IN ONCOLOGY PRACTICE AT DIFFERENT STAGES OF TREATMENT}

\section{Kyiv City Clinical Cancer Center}

@I. R. Mukharovska

SUMMARY. The aim of the study was to identify psychological phenomenon in different stages of the treatment.

The research conducted at the Kyiv City Clinical Cancer Center, participated 187 patients who underwent anticancer treatment at first time, 155 persons with cancer re-treatment and 112 palliative patients.

The leading psychological phenomenon at the stage of primary anticancer treatment were "separation of life" and "new beginning", in symptomatic care - "pendulum", "decentralization" and "externalization". The progression of disease and repeated anticancer therapy characterized decreasing primary and increasing palliative phenomena. Crosscutting phenomena were "induction" and "sorter".

The psychological condition of cancer patients formed in conjunction with the features of the stages of the treatment.

KEY WORDS: cancer patients, psychological status, psychological phenomena, psychooncology, psychological help.

Отримано 21.08.2016 